\title{
Teaching Quality, Learning Satisfaction, and Academic Performance among Hospitality Students in Taiwan
}

\author{
Wen-Hwa Ko ${ }^{1, *} \&$ Feng-Ming Chung ${ }^{1}$ \\ ${ }^{1}$ Department of Restaurant, Hotel and Institutional Management, Fu-Jen University, New Taipei city, Taiwan \\ *Corresponding author: Department of Restaurant, Hotel and Institutional Management, Fu-Jen University, No.510, \\ Zhongzheng Rd., Xinzhuang Dist., New Taipei City, Taiwan. Tel: 886-2-2905-3755. E-mail: \\ 073770@mail.fju.edu.tw
}

Received: July 23, 2014

Accepted: August 22, $2014 \quad$ Online Published: September 4, 2014

doi:10.5430/wje.v4n5p11

URL: http://dx.doi.org/10.5430/wje.v4n5p11

\begin{abstract}
The purpose of this study is to examine the effect of the teaching quality of culinary arts teachers and student learning satisfaction on the academic performance of hospitality students. This study surveys the students in hospitality departments at universities in Taiwan. A total of $406(81.2 \%)$ valid questionnaires were received. Research results show that there is a significant positive correlation between teaching quality of teachers and the learning satisfaction of students, between teaching quality of teachers and the academic performance of students, and between the learning satisfaction of students and the academic performance of students. The learning satisfaction of students has a mediating effect on the relationship between the teaching quality of teachers and the academic performance of students.
\end{abstract}

Keywords: teaching quality; learning satisfaction; academic performance; hospitality student

\section{Introduction}

The 21st century is a service-oriented age for Asia Pacific area. With the service industry expanding each year, the vocational and technical education system in Taiwan has added departments such as hospitality management and leisure and tourism, which have gradually become new popular courses of study. For training professionals in the food industry to keep pace with the high growth in this sector in Taiwan, demand for culinary arts teachers is increasing. Teacher quality is an important factor affecting student performance (Snehi, 2011). Thus, an urgent issue for both instructors and researchers is how to maintain teaching quality to enable students to achieve learning objectives and high learning performance (Becket and Brookes, 2008). Barr and Tagg (1995) indicate the education focus on the instructional effects of teachers, including teaching methods, curriculum, and materials of teachers, without focusing on the learning effects on students. In recent years, education has begun to emphasize learners, changing learning models to analyze students, and researching teachers to explore effective learning approaches. However, there are few studies on the teaching quality on culinary teacher and student learning. Thus, this study seeks to explore the effect of teaching quality of culinary arts teachers on the learning accomplishments of students.

\section{Literature Review}

\subsection{Teaching Quality}

Hunter (1979) proposed that teaching is the process of making decisions and executing approaches to improve learning possibilities before, during, and after teaching students. Ander and Burns (1990) argued that teaching is an activity of interpersonal interaction that involves language as communication, and can help students learn or change their learning behavior. However, teaching is not merely explaining or hinting at rigid instructional materials. Instructors need to establish good learning environments, through which to elicit learning motivation and teach learners to learn on their own, and understand how to learn by doing and do by learning (Vermeule and Schmidt, 2008). Teaching involves more than "teaching" and "learning". It is a composite concept that implicates complex concepts and activity processes. Teaching is also an activity that involves interpersonal interactions between the 
teacher, learner, and language, which in turn changes the learning attitudes of learners, or the overall process by which teachers and students jointly share and explore accomplishments, achieving the objectives and ideals of education (Kyriakides, Campbell and Christofidou, 2002).

Quality assurance refers to the planned and systemic actions necessary to provide adequate confidence that a product or service will satisfy given requirements for quality(Borahan and Aiarati, 2002). Deming (1982) defined quality as "the work performance of producing the most useful products on the market in most economical ways." Juran (1986) defined quality as whether customer needs can be satisfied, thus it is defined as "suitable for use." White, Wyne, Stuck, \& Coop (1987) stated that there are clusters of behaviors strongly related to student learning, including management of instructional time, management of student behavior, instructional presentation, instructional monitoring, and feedback. Dewar (2002) showed that empathy, accessibility, and good presentation are the most important issues in being a good teacher. Teaching awards, innovations in teaching research grants, training courses, and organizational commitment are also required for effective teaching and teachers. In summing up the definitions of these scholars for the meaning of quality, this study extends "quality" to teaching quality: promoting common understandings of instructional guidelines and school policies among teachers, and being able to satisfy student needs and create unique and appropriate characteristics in the instructional process, and that teachers' services and instructional goals can satisfy the expectations of students and parents, in turn eliciting student potential to achieve the educational objectives expected by students and parents (Ko and Chiu, 2011).

\subsection{Learning Performance}

Learning is a complex construct that is difficult to define. Most definitions of learning describe it as a relatively permanent change in behavior or ability in response to practice or experience (Shuell, 1986). Learning outcomes show a significant relationship with success in the initial phase of gradates' careers (Vermeulen and Schmidt, 2008). Student feedback is increasingly being considered as an important indicator of the quality of education (Harvey, 2001). Student feedback such as performance, including academic performance and student satisfaction, is important in understanding the students' perspective on their learning experiences. However, it may not necessarily represent what students have learned (Sockalingam, 2013).

Ko (2012) pointed out that learning satisfaction is the extent of satisfaction with learners regarding the learning process and the results of performance. Many scholars have used learning satisfaction as indicators of learning performance (Alavi, Yoo \& Vodel, 1997; Marki, Maki, Patterson \& Whittaker, 2000). They see learning satisfaction as one of the indicators for measuring learning performance, or see the learner as the focus in conducting feedback, in order to evaluate the extent to which learning objectives and ideals have been achieved. This is a method of self-evaluation. In Howard and Maxwell (1980), the measure of satisfaction was two items, including I would like to take another course from this instructor, and I have more positive feelings towards this field of study after taking this course. Pike (1991) used peer involvement, faculty involvement, and cultural involvement to measure satisfaction. There are several existing studies that have investigated student satisfaction and student performance (grades). While some argue against the use of grades as a measure of the quality of education, in practice all educational institutions use grades. To this day, an important criterion for employment is grades. As grades are a direct measure of the students' knowledge, it is common to use grades to estimate student performance. Increasingly, student satisfaction is also becoming an important indicator of the quality of teaching. Several studies suggest that both student satisfaction and grades are important indicators of student retention (Aitken, 1982; Bean, 1980).

Grades represent measurable indicators of learning performance. These include the scores of learners before and after undergoing the course, or mid-term and final grades (Piccoli, Ahmad \& Ives, 2001). Scholars see learning scores as indicators of learning effects, or a type of real assessment by teachers used to evaluate the performance of learners in achieving learning objectives. Ko (2012) found a positive correlation between effective learning, professional competence, and learning performance, which included measures of job satisfaction, course satisfaction, practice scores, and semester GPA.

\subsection{Correlations of Teaching Quality of Teachers, Learning Satisfaction, and Academic Performance}

Astin (1993) asserts that high-quality interactions between students, their peers, and faculty around intellectually meaningful subjects provides the most productive gains in learning outcomes. Kember (2004) believed that the exploration and assessment of the nature of teaching is teaching quality, and explained that teaching quality is the gap between teaching plans and the teaching activities as practiced. Other factors such as school environment, classroom peers, curricular design, teaching goals, teaching rules, and teaching environment all affect the learning performance of students. 
Roebken (2007) argued that teachers can conduct good curriculum planning and selection of suitable instructional materials, observe individual differences of students, apply individualized teaching, and use the results of diverse assessment to improve their teaching. If so, under the guidance of teachers, students can achieve effective learning, and apply what they have learned to their daily lives. Ramsdem and Entwistle (1981) obtained evidence that students' academic progress relates strongly to organized study methods and positive attitudes to studying. Students who reported the highest levels of learning and satisfaction also reported the highest levels and quality of interaction with the instructor and with other students (Shea, Fredericken, Pickett, Pelz, and Swan, 2013). Teachers may apply a variety of instructional strategies, resources, and media, and use teaching objectives and student characteristics to guide student learning, to enhance the learning effects and learning satisfaction of learners, in turn achieving the learning objectives of students (Dewar, 2002). In view of the above literature, that the first hypothesis is constructed:

H1: There is a positive correlation between the teaching quality of teachers and the learning satisfaction of students.

Since the teaching quality of teachers has a significant effect on learning performance, it is necessary to emphasize teaching quality of teachers (Ko, 2012). Liu and Jung (1980) have found that student satisfaction and grades are correlated. Pike (1991) examined that satisfaction influences grades. This study deduces that if teachers have good teaching quality, this can help enhance the learning performance of students to achieve higher learning scores and learning satisfaction. Hence:

H2: There is a positive correlation between the teaching quality of teachers and the academic performance of students.

H3: Teaching quality of teachers affects the learning satisfaction and academic performance of students, and learning satisfaction is the mediating factor between teaching quality and academic performance.

This study uses the teaching quality of culinary arts teachers as the independent variable, and learning performance as the dependent variable. Learning performance is divided into the two dimensions of learning satisfaction and academic performance, with learning satisfaction as the mediating variable, to explore whether there are significant correlations between teaching quality, learning satisfaction, and academic performance. The correlations among variables are explored in this framework. The research framework is shown Figure 1:

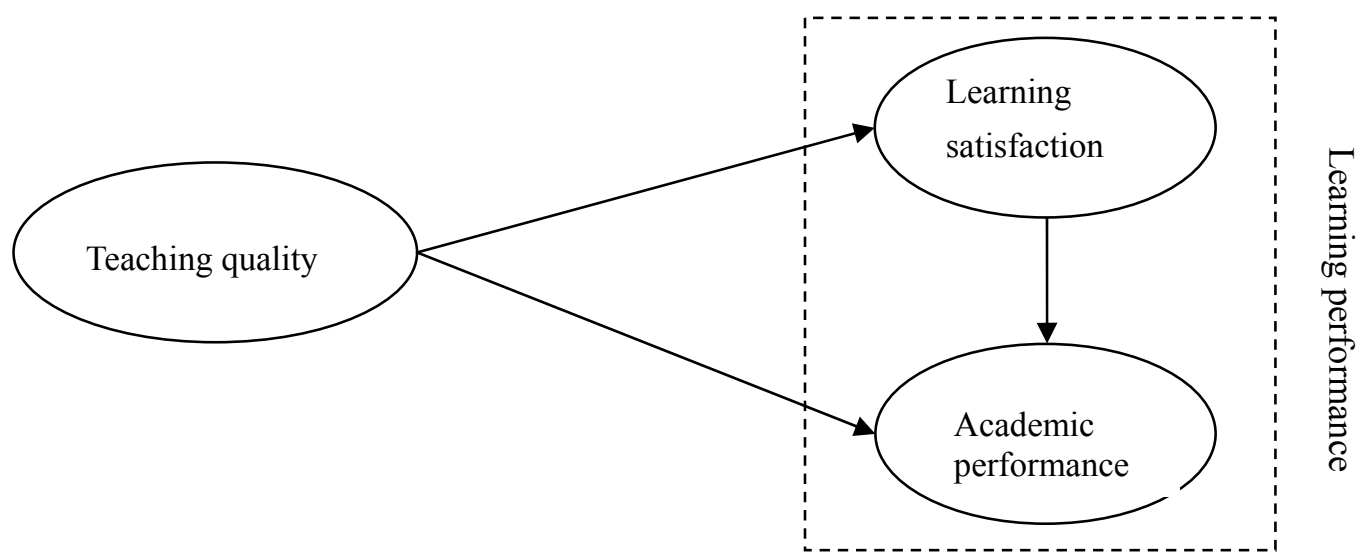

Figure 1. Research Framework

\section{Method}

\subsection{Sample and Data Collection}

Participants in this study consisted of students in hospitality departments in universities of Taiwan, with samples collected from northern, central, southern, and eastern Taiwan, as well as the offshore islands. They were all thirdand fourth-year students in hospitality departments, to ensure they had robust experience with culinary arts curriculum. Convenience sampling was used, since this study requires a high degree of accommodation by respondents. Thus, it is necessary to first find universities that were willing to undergo the survey. The researcher contacted the department secretaries or teachers themselves to explain the purpose of the study and after receiving their consent, the questionnaires are delivered in person or by mail to the schools, asking the department secretaries 
and teachers to assist in releasing and retrieving questionnaires. About a week later, the researchers followed-up by phone to increase questionnaire retrieval rates. Five hundred questionnaires were sent out. After eliminating invalid questionnaires, 406 (81.2\%) were retained for analysis.

\subsection{Measures}

The questionnaire used in this study has three parts: an evaluation of teaching quality, an evaluation of learning satisfaction and the basic personal data of students. The mean scores of students in culinary arts courses and the learning satisfaction section are used to test learning performance of students. Items in all scales were rated using a five-point Likert-type scale, ranging from 1 (strongly disagree) to 5 (strongly agree).

The construction of the teaching quality scale for culinary arts teachers is based on Ko and Chiu (2011). This study modifies the original scale into a scale suitable for culinary arts teachers with industry experience. If the score is high, it means that culinary arts teachers with industry experience perceive high teaching quality in themselves. If the score is low, they perceive low teaching quality. The pre-testing data were analyzed using item analysis and factor analysis. We used item analysis to assess the performance of individual test items, assuming that the overall quality of a test derives from the quality of its items. We evaluated the index of item analysis including mean, standard deviation, corrected item-total correlation, skewness, and item discrimination. Further, factor analysis was first used as an exploratory method (Field, 2005). Exploratory factor analysis (EFA) explores the relationships among the observed indicators with regard to their basic factors. Varimax rotation was used for the EFA in this study. Then, the second-order factor CFA was analyzed. Fourteen measurement items of teaching quality were found to load onto three factors: professional educational ability, professional culinary ability, and professional educational spirit and attitude. Bentler and Chou (1987) suggested that the 14 measurement items reduced to 3 factors for optimal structural equation modeling analysis. Cronbach's $\alpha$ ranged from 0.933 to 0.944 for the three constructs, showing good reliability.

Learning satisfaction: This scale uses the learning satisfaction questionnaire of Ko (2012), which is a student self-evaluation questionnaire. This study modifies the original scale into a scale suitable for the learning satisfaction of students after undergoing culinary arts courses. Cronbach's $\alpha$ for all scales was 0.812 . Then, students' self-evaluated learning satisfaction and average scores in culinary courses were used to assess student learning performance.

\subsection{Data Analysis}

The collected data were analyzed using Statistical Package for Social Sciences (SPSS), version 18.0. The quantitative statistical methods include reliability analysis, factor analysis, and descriptive statistical analysis.

The analysis uses a two-step procedure consisting of the measurement model analysis and the structural equation model (SEM) analysis (Anderson and Gerbing, 1988). In the measurement model analysis, we examined the reliability and discriminant validity among the variables. We assessed the hypothesized theoretical model and estimated parameters for the next structural model analysis. To perform the SEM analysis, we used Maximum Likelihood (ML) and estimated the parameters since LISREL assumes multivariate normality of the data (Version 8.54)(Bollen, 1989). The overall fit index of the model is as follows: chi-squared statistic adjusted by the degrees of freedom $\left(\chi^{2} / \mathrm{df}\right)$, root mean square error of approximation (RMSEA), standardized root mean square residual (SRMR), comparative fit index (CFI), normed-fit index (NFI), and goodness- fix index (GFI) were evaluated. The

value of the $\chi^{2} / \mathrm{df}$ ratio should be less than 5; less than 3 is better (Joreskog and Sorbom, 1993). An RMSEA and SRMR value at or below 0.08 shows good fit, while 0.08 to 0.1 demonstrates mediocre fit (Browne and Cudeck, 1992). GFI, CFI, and NFI values of over 0.90 indicate a good fit.

\section{Results}

\subsection{Participant Demographic}

According to Table1, most are third- and fourth-year students, female, and have a Chinese culinary arts Level C certification. Most (66.5\%) have less than a year to two years of experience in hospitality work or internships. The majority $(80.5 \%)$ has not participated in food preparation skill competitions, and over $90 \%$ of them plan to work in hospitality-related industries after graduation. Average scores in culinary arts classes are mostly between 70 and 89 . 
Table 1. Descriptive Statistics of the Participants

\begin{tabular}{|c|c|c|c|c|c|c|c|}
\hline \multicolumn{2}{|c|}{ Personal background variables } & $\mathrm{N}$ & Percent (\%) & Personal ba & ckground variables & $\mathrm{N}$ & Percent (\%) \\
\hline \multirow{2}{*}{ Gender } & Men & 148 & 36.5 & \multirow{5}{*}{$\begin{array}{l}\text { Work or internship } \\
\quad \text { experience }\end{array}$} & Never & 42 & 10.3 \\
\hline & Women & 258 & 63.5 & & Less than 1 year & 102 & 25.1 \\
\hline \multirow{2}{*}{ Year } & Third & 286 & 70.4 & & Between 1-2 years & 168 & 41.4 \\
\hline & Fourth & 120 & 29.6 & & Between 2-3 years & 53 & 13.1 \\
\hline \multirow{9}{*}{$\begin{array}{l}\text { Culinary } \\
\text { technician } \\
\text { certification }\end{array}$} & No certification & 99 & 24.4 & & 3 years or more & 41 & 10.1 \\
\hline & $\begin{array}{l}\text { Chinese cooking } \\
\text { Level C }\end{array}$ & 233 & 57.4: & \multirow{3}{*}{$\begin{array}{l}\text { Participated in } \\
\text { culinary skills } \\
\text { competitions }\end{array}$} & Never & 327 & 80.5 \\
\hline & $\begin{array}{l}\text { Western cooking } \\
\text { Level C }\end{array}$ & 41 & 10.1 & & At least once a year & 58 & 14.3 \\
\hline & $\begin{array}{l}\text { Hospitality services } \\
\text { Level C }\end{array}$ & 73 & 18.0 & & $\begin{array}{l}\text { At least once every two } \\
\text { years }\end{array}$ & 21 & 5.2 \\
\hline & Beverage Level C & 145 & $35.7^{\ddagger}$ & \multirow{4}{*}{$\begin{array}{l}\text { Willingness to } \\
\text { work in hospitality } \\
\text { industries after } \\
\text { graduation }\end{array}$} & Impossible & 11 & 2.7 \\
\hline & Baking Level B & 174 & 42.9 & & Slightly possible & 124 & 30.5 \\
\hline & $\begin{array}{l}\text { Chinese baking Level } \\
\text { C }\end{array}$ & 19 & 4.7 & & Possible & 166 & 40.9 \\
\hline & $\begin{array}{l}\text { Chinese cooking } \\
\text { Level B }\end{array}$ & 5 & 1.2 & & Very possible & 105 & 25.9 \\
\hline & Other & 31 & 7.6: & & Under 59 & 5 & 1.2 \\
\hline \multirow{4}{*}{$\begin{array}{l}\text { Self-study and } \\
\text { advancement }\end{array}$} & Never & 294 & 72.4 & \multirow{4}{*}{$\begin{array}{c}\text { Average academic } \\
\text { scores in culinary } \\
\text { courses } \\
(0-100 \text { points })\end{array}$} & $60-69$ & 32 & 7.9 \\
\hline & $\begin{array}{l}\text { Once every six } \\
\text { months }\end{array}$ & 77 & 19.0 & & $70-79$ & 124 & 30.5 \\
\hline & Once a year & 21 & 5.2 & & $80-89$ & 206 & 50.7 \\
\hline & Once many years & 14 & 3.4 & & Over 90 & 39 & 9.6 \\
\hline
\end{tabular}

Note: Total N=406

\subsection{Correlations between Teaching Quality, Learning Satisfaction, and Academic Performance}

In order to understand the correlations between teaching quality, learning satisfaction, and academic performance, this study uses the results of Pearson correlation analysis. We compile the results of the correlation analysis in Table 2. There are significant positive correlations between teaching quality, learning satisfaction, and academic performance.

Table 2. Means, Standard Deviations, and Correlations among Constructs ${ }^{\text {a }}$

\begin{tabular}{lccccc}
\hline Variables & Mean & SD & $\begin{array}{c}\text { Teaching } \\
\text { quality }\end{array}$ & $\begin{array}{c}\text { Learning } \\
\text { satisfaction }\end{array}$ & $\begin{array}{c}\text { Academic } \\
\text { performance }\end{array}$ \\
\hline $\begin{array}{l}\text { Teaching quality } \\
\text { Learning } \\
\text { satisfaction }\end{array}$ & 3.92 & 0.449 & - & & \\
$\quad \begin{array}{l}\text { Academic } \\
\text { performance }\end{array}$ & 3.88 & 0.638 & $.672^{* * *}$ & - & \\
${ }^{a} \mathrm{~N}=406$ & 3.63 & 0.823 & $.344^{* * *}$ & $.359^{* * *}$ & - \\
$P<0.001$ & & & & &
\end{tabular}

\subsection{Effect of Teaching Quality and Learning Satisfaction on Academic Performance}

Using Anderson and Gerbing's (1988) two-step approach, the measurement model was analyzed using CFA to confirm the research constructs. CFA matches the traditional scale development process providing an alternative measure of the internal and external consistency of the scale items (Sethi and King 1994). As shown in Table 3, Cronbach's $\alpha$ of each measurement scale was higher than 0.8. Composite reliability of each measurement scales ranged from 0.84 to 0.86 , demonstrating internal consistency between corresponding constructs. The average variance extracted (AVE) of all constructs, 0.5, surpassed the minimum value (Fornell and Lacker1981). Discriminant and convergent validity were ensured.

We next used structural equation model analysis to establish the structural equation modeling (SEM) among the 
three dimensions of teaching quality, learning satisfaction, and academic performance. The first stage conducts the test for model fit, followed by confirmation of causal relationships among variables in the second stage, including the direct effect of teaching quality on learning satisfaction, the direct effect of learning satisfaction and academic performance, the direct effect of teaching quality on academic performance, and finally confirms whether learning satisfaction would have a mediating effect on teaching quality and academic performance (Fig. 2).

This study compiles the outcomes of overall model fit in Table 4 , which shows that the chi-square value $(\chi 2=78.31$, $\mathrm{df}=18, \mathrm{p}<.001)$ reaches the level of significance, since chi-square values are very sensitive to sample number. Thus, Hair, Anderson, Tatham, \& Black (1998) suggested that the ratio of chi-square and degrees of freedom $\left(\chi^{2} / \mathrm{df}\right)$ should be used as the measurement indicator. In this study, $\chi^{2} / \mathrm{df}=4.35$, chi-square $\mathrm{p}$ value $=0.00$, $\mathrm{RMSEA}=0.091$, which is still acceptable; and SRMR $=0.043, \mathrm{CFI}=0.98, \mathrm{NNFI}=0.97$, GFI $=0.95$ all exhibit good fit. The overall fit of this model is within the ideal range.

Table 3. Properties of the Measurement Model

\begin{tabular}{|c|c|c|c|c|c|}
\hline Constructs & $\begin{array}{l}\text { Standardized } \\
\text { factor loadings }\end{array}$ & Cronbach's $\alpha$ & $\begin{array}{l}\text { Composite } \\
\text { Reliability }\end{array}$ & $\begin{array}{c}\text { Average } \\
\text { Variance } \\
\text { Extracted }\end{array}$ & Mean \\
\hline Teaching quality $^{\mathrm{a}}$ & & 0.95 & $0.86^{\mathrm{b}}$ & 0.67 & \\
\hline TQ1: Professional educational ability & 0.86 & & & & 3.89 \\
\hline TQ2: Professional culinary ability & 0.79 & & & & 4.05 \\
\hline $\begin{array}{l}\text { TQ3: Professional educational spirit and } \\
\text { attitude }\end{array}$ & 0.81 & & & & 3.82 \\
\hline Learning satisfaction & & 0.81 & $0.84^{\mathrm{c}}$ & 0.57 & \\
\hline $\begin{array}{l}\text { LS1: Satisfaction with instructional } \\
\text { planning }\end{array}$ & 0.80 & & & & 3.92 \\
\hline $\begin{array}{l}\text { LS2: Satisfaction with arrangement of } \\
\text { procedures }\end{array}$ & 0.82 & & & & 3.86 \\
\hline LS3:Satisfaction with time arrangements & 0.70 & & & & 3.80 \\
\hline LS4:Satisfaction with curriculum design & 0.69 & & & & 3.95 \\
\hline Academic performance & 1.00 & & & & 3.63 \\
\hline
\end{tabular}

Table 4. Goodness of Fit Indices for the Model

\begin{tabular}{lcc}
\hline \multicolumn{1}{c}{ Test indicators } & Standard & Value \\
\hline Chi-square and degrees of freedom ratio $\left(\chi^{2} / \mathrm{df}\right)$ & $<5$ & 4.35 \\
Root Mean Square Error of Approximation, RMSEA & $<0.08$ & 0.091 \\
Standardized Root Mean square Residual, SRMR & $<0.08$ & 0.043 \\
Comparative Fit Index, CFI & $>0.9$ & 0.98 \\
Normed-Fit Index, NFI & $>0.9$ & 0.97 \\
Goodness of Fit Index, GFI & $>0.9$ & 0.95 \\
\hline
\end{tabular}

This study primarily explores the correlations between teaching quality, learning satisfaction, and academic performance. The direct effects, indirect effects, and overall effects between the variables are used to understand the direct effect of independent variables on endogenous variables as well as the indirect mediating effects on other potential variables.

This study uses the completely standardized solution estimated from the path model in Figure 2, which explains the direct and indirect effects among research variables, as shown in Table 5. The direct effect of teaching quality on academic performance is 0.16 ( $>0.05)$, the direct effect of teaching quality on learning satisfaction is $0.77(p<0.001)$, the direct effect of learning satisfaction on academic performance is $0.27 \quad(p<0.001)$, and through learning satisfaction, the indirect effect of teaching quality on academic performance is $0.21(\mathrm{p}<0.001)$. According to Jung (2008), if the indirect effect is greater than the direct effect, it shows that the mediating effect exists. Thus hypotheses 1,2 , and 3 are all supported by the empirical evidence. 


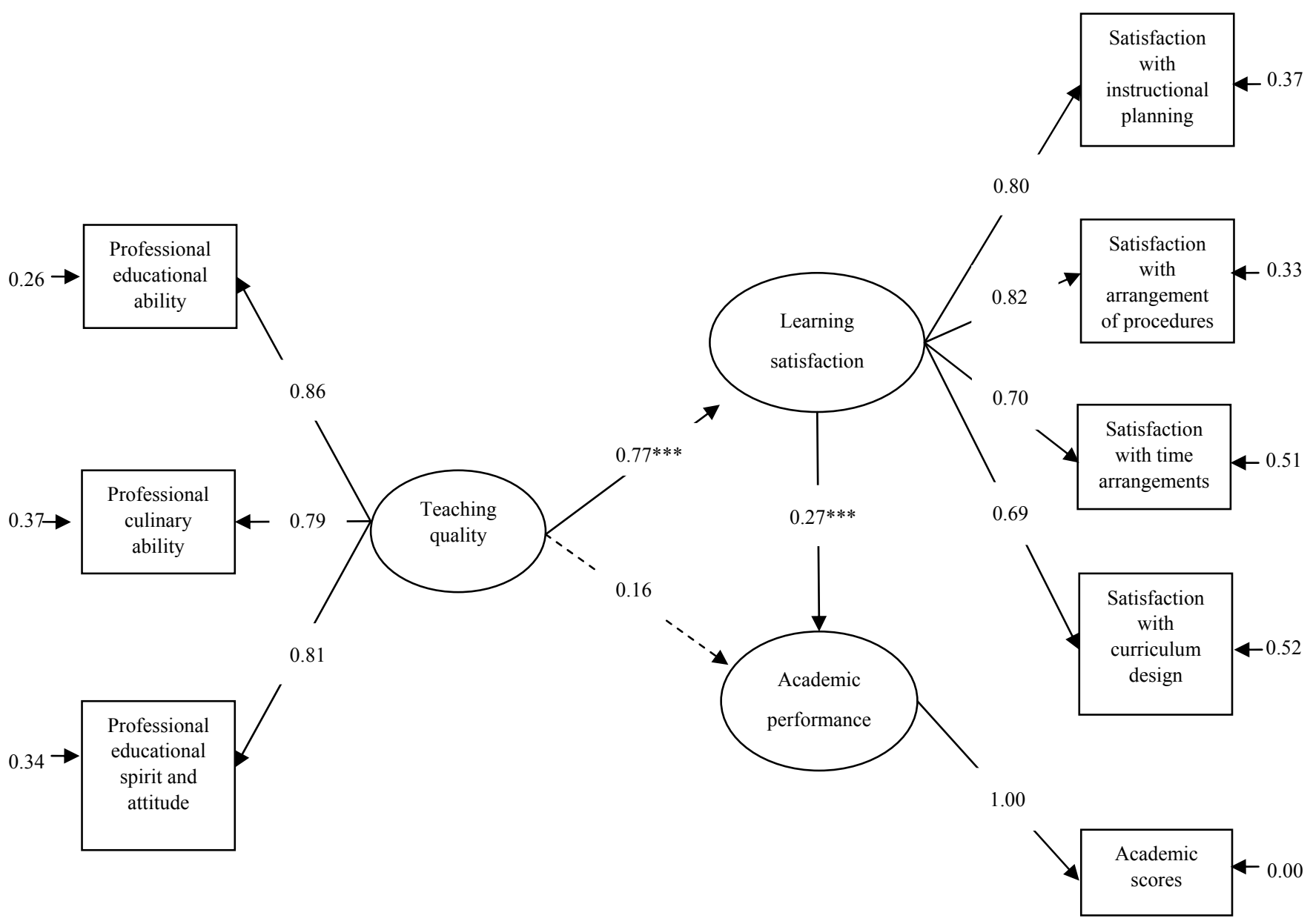

Figure 2. The Relationship Path Diagram (SEM) of Teaching Quality, Learning Satisfaction, and Academic Performance

Table 5. Analysis of Relationships between Teaching Quality, Learning Satisfaction, and Academic Performance

\begin{tabular}{ccc}
\hline & \multicolumn{2}{c}{ Endogenous variables } \\
\cline { 2 - 3 } Independent variables & Learning satisfaction & Academic performance \\
\hline Teaching quality & $0.77^{* * *}$ & 0.16 \\
Direct effect & -- & $0.21^{* * *}$ \\
Indirect effect & $0.77^{* * *}$ & $0.37^{* * *}$ \\
Overall effect & -- & $0.27^{* * *}$ \\
Learning satisfaction & -- & -- \\
Direct effect & -- & $0.27^{* * *}$ \\
Indirect effect & -- & Overall effect
\end{tabular}

Note: $* * * \mathrm{p}<0.001$

\section{Conclusions and Discussion}

\subsection{Conclusions and Discussion}

The purpose of this study is to understand the current conditions of hospitality students at universities regarding teaching quality of teachers and student learning performances. Most of the survey students have a cooking Level C 
as their food-related technician certification and have food-related work or internship experience of 1-2 years, but $72.4 \%$ of the participants do not study on their own for advancement and have never participated in food skills competitions. However, the students plan to work in hospitality work after graduation. Grades in culinary arts courses most commonly fall between $80-89$ points $(50.7 \%)$, followed by $70-79$ points $(30.5 \%)$.

Our empirical results show that there is a significant positive correlation between teaching quality of teachers and the learning satisfaction of students. Hence, if students perceive good teaching quality from their teachers, students will experience good learning satisfaction. There is a significant positive correlation between teaching quality of teachers and the academic performance of students. Thus, if students perceive good teaching quality in teachers; they exhibit good academic performance. There is a significant positive correlation between the learning satisfaction of students and the academic performance of students. If students have good learning satisfaction, then they will have good academic performance. However, Pike (1991) examined the reciprocal relationship between grades and satisfaction using a latent variable model in which grades and satisfaction are latent variables rather than direct measures. Sockalingam (2013) showed that satisfaction on assessment had a direct influence on the course grades but only explained $1.3 \%$ of the variance in a grade. Satisfaction on assessment was in turn positively and directly influenced by course content and course design.

However, there are many reasons that teaching quality will affect learning satisfaction and increase learning grade. Pavesic (1984) and Lefever and Withian (1998) emphasized the important of using experiential learning opportunities, in the form of internships and work requirements, hands-on learning experience in the classroom, and courses taught by faculty with industry experience, in evaluating program quality. The required internship and work experience, as well as participation in community events and competitions, are important quality indicators that reflect the importance of experiential learning (Lefever \& Withian, 1998). Low student to faculty ratios, in classrooms and laboratories can facilitate more interaction with faculty and peers, and thus increase learning and satisfaction (Astin, 1993). Vermeulen and Schmidt (2008) showed that a good teacher-student and student-student interactions increase student learning outcomes. Paraskevas and Sigala (2003) suggested that students can develop their intellectual skills with the assistance of teacher. Howard and Maxwell (1980) compared a student motivation model with the grading leniency model. According to the student motivation model, satisfaction itself does not determine grade. Their study showed that satisfaction correlated much more with student motivation and progress than with grades, implying that student satisfaction is not contaminated by grades.

The results show that the learning satisfaction of students has a mediating effect on the relationship between teaching quality of teachers and the academic performance of students. This implies that the teaching quality of teachers elevates the academic performance of students through the mediating effect of the learning satisfaction of students. In practice, this means that the professional educational ability, professional culinary ability, and professional educational spirit and attitude of teachers all affect the learning satisfaction of students. Further, the professional educational ability, professional culinary ability, and professional educational spirit and attitude of teachers and learning satisfaction of students in turn affects their academic performance. Thus, in order to elevate academic performance, it is necessary to find ways to elevate the teaching quality of teachers. The quality of teaching has a significant impact on the quality of student learning, and this in turn has strongly related to the concept of teaching adhered to by the teachers. In general, teachers who adopt a student-centered teaching approach motivate students to engage in their own learning (Chan and Tang, 2006).

\subsection{Research Limitation}

This study suffers from several limitations. We used questionnaire surveys to carry out evaluations of the teaching quality of culinary arts teachers by university students in hospitality departments. If it is possible to match this with qualitative studies, such as observations or case studies, researchers, administrators, and teachers would obtain greater understanding of the difficulties faced by hospitality majors in their work in culinary arts classes. This would make the research results more comprehensive and concrete. Second, the questionnaire in this study uses student self-evaluations to evaluate the teaching quality of culinary arts teachers. If it is possible to add teachers' self-evaluations of their teaching quality, then conduct matched sample tests with the self-evaluated teaching quality by students, to unify the perspectives of students and teachers, the research data would be more precise. 


\section{References}

Aitken, N.D. (1982). College student performance, satisfaction, and retention: Specification and estimation of a structural model. The Journal of Higher Education, 53(1), 32-50. http://dx.doi.org/10.2307/1981537

Alavi, M., Yoo, Y., \& Vogel, D. R. (1997). Using information technology to add value to management education. Academy of Management Journal, 40(6), 1310-1334. http://dx.doi.org/10.2307/257035

Ander, L. W., \& Burns, R. B. (1990). Research in Classrooms: The study of Teachers, Teaching and Instruction. New York, Macmillan Pergamon presses.

Anderson, J.C., \& Gerbing, D.W. (1988). Structural modeling in practice: a review and recommended two-step approach. Psychological Bulletin, 103, 411-423. http://dx.doi.org/10.1037/ 0033-2909.103.3.411

Astin, A.W. (1993). What matters in college: four critical years revisited. San Francisco, CA: Jossey- Bass.

Barr, R. B., \& Tagg, J. (1995). From teaching to learning: A new paradigm for undergraduate education. Change, 27, 12-15. http://dx.doi.org/10.1080/00091383.1995.10544672

Bean, J.P. (1980). Dropouts and turnover: The synthesis and test of a causal model of student attrition. Research in Higher Education, 12(2), 155-187. http://dx.doi.org/10.1007/BF00976194

Becket, N., \& Brookes, M. (2008). Quality management practice in higher education - what quality are we actually enhancing? Journal of Hospitality, Leisure, Sport \& Tourism Education, 7(1), 40-54. http://dx.doi.org/10.3794/johlste.71.174

Bentler, P.M., \& Chou, C. (1987). Practical issues in structural modeling. Sociological Methods and Research, 16, 78-117. http://dx.doi.org/10.1177/0049124187016001004

Bollen, K.A. (1989). Structural equations with latent variables. New York: Wiley. http://dx.doi.org/10.1002/9781118619179

Borahan, N.G., \& Ziarati, R. (2002). Developing quality criteria for application in the higher education sector in Turkey. Total Quality Management, 18(4), 224-242

Browne, M.W., \& Cudeck, R. (1992). Alternative ways of assessing model fit. Sociological Methods and Research, 21, 230-258. http://dx.doi.org/10.1177/0049124192021002005

Chan, B., \& Tang, W. (2006). Evaluating the impact of university teaching on approaches to learning of first- year hospitality students. Journal of Teaching in Travel \& Tourism, 6(1), 41-59. http://dx.doi.org/10.1300/J172v06n01_03

Deming, E. W. (1982). Quality Productivity and Competitive Position. Cambridge, MA: MIT Center for advanced Engineering Study.

Dewar, K. (2002). On be a good teacher. Journal of Hospitality, Leisure, Sport \& Tourism Education, 1(1), 61-67. http://dx.doi.org/10.3794/johlste.11.14

Field, A. (2005). Discovering statistics using SPSS. SAGE Publications Ltd. London.

Fornell, C., \& Larcker, D.F. (1981). Evaluating structural equation models with unobservable variables and measurement error. Journal of Marketing Research, 18, 39-50. http://dx.doi.org/10.2307/3151312

Hair, J.F., Anderson, R.E., Tatham, R.L., \& Black, W.C. (1998). Multivariate Data Analysis.(5 ${ }^{\text {th }}$ Ed.). Prentice-Hall, New Jersey.

Harvey, L. (2001). Student feedback: a report to the higher education funding council for England. London: HEFCE.

Howard, G.S., \& Maxwell, S.E. (1980). Correlation between student satisfaction and grades: A case of Mistaken causation? Journal of Educational Psychology, 72(6), 810-820. http://dx.doi.org/10.1037/0022-0663.72.6.810

Hunter, M. (1979). Teaching Is Decision Making. Educational Leadership, 37(1), 62-67.

Joreskog, K.G., \& Sorbom, D. (1993). LISREL 8: User's Reference Guide. Scientific Software International. Chicago, I.L.

Juran, J. M. (1986). A Universal Approach to Managing for Quality. Quality Process, 12, 19-24.

Kember, D. (2004). Interpreting student workload and the factors which shape students' perception of their workload. Studies in Higher Education, 29(2), 165-184. http://dx.doi.org/10.1080/0307507042000190778

Ko.W. H., \& Chiu, Y.H. (2011). To develop the teaching quality indicators for the culinary teacher in the university. 
World Transactions on Engineering \& Technology Education, 9(2), 114-118.

Ko.W.H. (2012). A study of the relationships among effective learning, professional competence, and learning performance in culinary field. Journal of Hospitality, Leisure, Sport \& Tourism Education, 11, 12-20. http://dx.doi.org/10.1016/j.jhlste.2012.02.010

Kyriakides, L., Campbell, R.J., \& Christofidou, E. (2002). Generating criteria for measuring teacher effectiveness through a self- evaluation approach: A complementary way of measuring teacher effectiveness. School Effectiveness and School Improvement, 13(3), 291-325. http://dx.doi.org/10.1076/sesi.13.3.291.3426

Lefever, M.M., \& Withian, G. (1998). Curriculum review: How industry views hospitality education. Cornell Hotel and Restaurant Administration Quarterly, 39(4), 70-79. http://dx.doi.org/10.1177/001088049803900411

Liu, R., \& Jung, L. (1980). The commuter student and student satisfaction. Research in Higher Education, 12(3), 215-226. http://dx.doi.org/10.1007/BF00976093

Marki, R. H., Maki, W. S., Patterson, M., \& Whittaker, P. D. (2000). Evaluation of a web-based introductory psychology course: I. learning and satisfaction in on-line versus lecture courses. Behavior Research Methods, Instrument \& Computer, 32(2), 230-239. http://dx.doi.org/10.3758/BF03207788

Paraskevas, A., \& Sigala, M. (2003). Teaching hospitality and tourism management: A matter of style. Journal of Teaching in Travel \& Tourism, 3(4), 1-18. http://dx.doi.org/10.1300/J172v03n04_01

Pavesic, D.V. (1984). Educator- industry perceptions of the subject- area importance of hospitality programs. Hospitality Research and Education Journal, 9(1), 13-29. http://dx.doi.org/10.1177/109634808400900103

Piccoli, G., Ahmad, R., \& Ives, B. (2001). Web-based virtual learning environments: A search framework and a preliminary assessment of effectiveness in basic IT skills training. MIS Quarterly, 25(4), 401-427. http://dx.doi.org/10.2307/3250989

Pike, G.R. (1991). The effects of background, coursework, and involvement on students' grades and satisfaction. Research in Higher Education, 32(1), 15-30. http://dx.doi.org/10.1007/BF00992830

Ramsden, P., \& Entwistle, N.J. (1981). Effect of academic department on students' approaches to studying. British Journal of Educational Psychology, 51, 368-383. http://dx.doi.org/10.1111/j.2044-8279.1981.tb02493.x

Roebken, H. (2007). The influence of goal orientation of students satisfaction, academic engagement and achievement. Electronic Journal of Research in Educational Psychology, 5(3), 679-704.

Sethi, V., \& King, W.R. (1994). Development of measurement to assess the extent to which an information technology application provides competitive advantage. Management Science, 40, 1601-1624. http://dx.doi.org/10.1287/mnsc.40.12.1601

Shea, P., Fredericken, E., Pickett, A., Pelz, W., \& Swan, K. (2013). Measures of Learning Effectiveness in the SUNY Learning Network. Retrieved from http://www.suny.edu/sunytrainingcenter/files/ALNWorkshop2000.pdf

Shuell, T.J. (1986). Cognitive conceptions of learning. Educational Psychologist, 28(4), 291-320. http://dx.doi.org/10.1207/s15326985ep2804_1

Snehi, N. (2011). Improving teaching -learning process in schools: A challenge for the 21st century. Learning community, 2(1), 1-12.

Sockalingam, N. (2013). The relation between student satisfaction and student performance in blended learning curricula. The international Journal of Learning, 18(12), 121-134.

Vermeulen, L., \& Schmidt, H.G. (2008). Learning environment, learning process, academic outcomes and career success of university graduates. Studies in Higher Education, 33(4), 431-451. http://dx.doi.org/10.1080/03075070802211810

White, K., Wyne, M., Stuck, G., \& Coop, R.H. (1987). Assessing teacher performance using an observational Instrument based on research findings. NASSP Bulletin, March, 89-95. http://dx.doi.org/10.1177/019263658707149713 